\title{
BUSINESS CONDITIONS REGIONAL ANALYSIS WITH A REFERENCE TO POTENTIALS IN TOURISM DEVELOPMENT: THE CASE OF SERBIA
}

\author{
Đorđe Mitrović \\ Emilija Manić \\ Slobodan Ivanović
}

https://doi.org//10.20867/tosee.06.33

\begin{abstract}
Purpose - Tourism is one of the fastest-growing sectors in the world, and many developing countries saw it as the chance of economic development accelerating. However, tourism potential is different among countries as well as within one country. The scope of this paper is to reveal the regional differences in business conditions considering tourism development in Serbia. Methodology - Instead of using a wide number of different individual indicators measuring regions' tourism performances, it is more appropriate to use one composite indicator for depicting complex issues in regional tourism development - a composite index was developed using Data Envelopment Analysis. Data Envelopment Analysis is a sort of methodology that constructs an 'efficiency frontier' based on each region's individual data using mathematical linear programming. It determines the best practice by measuring the relative position of each of the regions in terms of the value of the set of observed indicators. Such presentation of the existing region's development in the tourism field and recommendations for possible improvement are clearer to the general public and non-scientific audience. The composite index is calculated as the weighted sum of the corresponding individual indicators, where the weights are endogenously determined by mathematical linear programming to obtain the maximum possible value.

Findings - The results of DEA showed which parts of Serbia have the best business conditions for tourism development, considering the different factors (regional development index and subindexes). The results have been contrasted to chosen tourism statistics on the regional level, with a reference to the limitations during the research process. The proposed composite index is used to point the differences in regional business conditions which could be further influenced by government policies to tackle the specificities and needs of each separate region during tourism development.

Contribution - DEA is a known methodology in regional development analysis, but it hasn't been so much used in business conditions regional analysis before. Having different indicators which shaped business climate within one region, using DEA one tried to analyze the entrepreneurship possibilities with a spatial reference to the tourism development. This is an important contribution in the context of local economic and social development especially within poorly developed regions in Serbia.
\end{abstract}

Keywords: business conditions, tourism, development, DEA, entrepreneurship.

\section{INTRODUCTION}

Tourism is one of the fastest-growing sectors in the world and the tourism industry impact is an impressive one: it contributed 10.4\% to the global GDP in 2019 (an overall tourism GDP value of over US\$ 9.7 trillion) and accounted for 344 million jobs. However, the expected further growth of the sector disturbed the Covid-19 pandemic in 
ToSEE - Tourism in Southern and Eastern Europe, Vol. 6, pp. 491-502, 2021.

Đ. Mitrović, E. Manić, S. Ivanović: BUSINESS CONDITIONS REGIONAL ANALYSIS WITH A ...

2020, strongly downsizing the performance of the tourism industry worldwide (WTTC 2021). Tourism GDP fell by $49.1 \%$ (-US $\$ 4.498$ trillion) while global GDP fell by $3.7 \%$, and the tourism employment rate globally fell by $18.5 \%$ (61.7 million jobs less) (WTTC 2021). It is clear that, whatever aspect analyzing, tourism has long been recognized as an important sector which has quite impact on overall economic activity.

Having in mind the importance of tourism within national economies even among those countries where it is not the leading economic activity, it was challenging to explore its structure and the operation mode within the context of the most influencing factors that shape it. This is even more interesting when it is analyzed within the context of regional disparities and the attempts of different areas to seize as many opportunities for development as possible. Sometimes tourism is seen as an opportunity for the economic development of undeveloped areas which is recognized as tourist potential. However, for the balanced and realistic regional development based on realistic foundations, it is important to investigate what are the factors that provide certain business climates and how these factors vary across the country, among the regions/areas.

\section{THEORETICAL BACKGROUND}

The tourism sector is significant for many countries, especially for those within which there are a certain amount of tourist destinations that generate a certain income. Worldwide as well as nationally, this is one of the fastest-growing sectors with quite an important impact on the economic activity (Dwyer et al. 2004, Mayer and Vogt 2016). Numerous researches investigate the relationship between tourism and economic growth globally and nationally, but also with a particular focus at the regional level (Sharpley 2002, Jackson et al. 2005, Che Chou 2013). On the other hand, having in mind the chance that tourism gives to the developing countries economic development accelerating, some researches taking into account the other side of this "multiplicator", having the realistic conditions under which tourism may lower both labor employment and welfare due to rising costs as well (Holzner 2011). Because tourism is one of the quite complex activities under the service sector with strong relations to many other economic activities and social aspects, not only its influence but also the factors that shape it, are important research topics today.

Different factors influence tourism development (McIntosh et al. 2009, Khanh Tuan and Rajagopal 2019). These factors work at the global, national, regional, and local levels, making different connections between objects and processes and producing a base for planning and managing tourism within the different scales of economy (Ryan 2009). Best practices and experiences of well-established tourist destinations are good guide marks for tourism development in less developed and peripheral areas, but it also must be considered the specificities of these areas, too (Buhalis 1999, Wanhill 1997, Blomgren and Sorenson 1998). Because of that, there is a certain number of tourism factors that could be considered as general with an emphasis on tourist potential destinations specificities that could make a difference in ranking these factors.

It is obvious there is a strong relationship between tourism development and infrastructure (Adebay and Iweka 2014, Petrova et al. 2018) but as well between overall 
ToSEE - Tourism in Southern and Eastern Europe, Vol. 6, pp. 491-502, 2021.

Đ. Mitrović, E. Manić, S. Ivanović: BUSINESS CONDITIONS REGIONAL ANALYSIS WITH A ...

development and tourism infrastructure, tourism, and the local economy (Swyngedouw 2000). Modernizing tourist infrastructure can certainly revive tourism in many regions, which in its turn can help the economic growth of regions, but one should also consider the standards of tourism services, innovative programmers, and promotion activity (Nicula et al. 2013). Having all these aspects in mind, investments in general, but also investments in tourist infrastructure, become an essential component of the more competitive and faster development tourist destination. In such a way tourist destinations but also areas that plan to develop tourism create certain business environments and infrastructure that have a strong positive correlation (Jovanovic and Ilic 2016). Important factors that improving business conditions impact tourism development are also human resources development with special reference to the leadership competencies (Blackman et al. 2004) and closer relationship with other branches of the economy because tourism increases the demand for the certain commodities (Adrain 2017).

Nominating the unbalanced regional development as one of the top five research topics in the economy and some other scientific fields (economic geography, sociology), it is noticeable that there is certainly a theoretical gap that concerns the imbalance between the application of theoretical and empirical approaches in explaining issues associated with tourism and regional development which resulted further with some new approaches such as regional competitiveness, regional polices on the maximum use of tourism performance or cluster concepts (Opperman 1993, Jackson and Murphy 2002, Santos Estêvão and Ferreira 2009, Nicula et al. 2013, Calero and Turner 2020). It is clear now that tourism has a certain impact on regional development and that it is correct to consider its importance for the local economy, but also that there is a feedback effect certain factors makes favorable business environment for tourism development within different areas/regions, too. So, in regional disparities topics, we should include not only the effects of human activity within regions/counties but also the differences between factors that shaped these regions in such different ways.

\section{METHODOLOGY}

\subsection{DEA methodology - general theoretical framework}

The composite indicator of tourism development and performance of districts in Serbia is built using Data envelopment analysis. This technique has been widely used to assess performance in the different fields (social, demographic, economic, ecological, technological, etc.) (Mitrović 2015; Mitrović 2020) and has been revealed as "a useful tool in policy analysis and public communication" (Nardo et al. 2005; Vidoli et al. 2015).

Data envelopment analysis is a sort of methodology which constructs an 'efficiency frontier' based on each district's individual data using mathematical linear programming and avoids subjectivity in the choice of weights. It determines the best practice by measuring the relative position of each of the districts in terms of the value of the set of observed indicators. Such presentation of existing district's development in different fields and recommendations for possible improvement is clearer to the general public and non-scientific audience because the indicators built using this approach are easily 
ToSEE - Tourism in Southern and Eastern Europe, Vol. 6, pp. 491-502, 2021.

Đ. Mitrović, E. Manić, S. Ivanović: BUSINESS CONDITIONS REGIONAL ANALYSIS WITH A ...

understandable for the general public, as they can be normalized to one composite index (OECD 2008).

To determine the weights for each district and each individual indicator, the "Benefit of the Doubt" approach is used (Charnes et al. 1978). The combination of weights, calculated through the process of linear programming, enables the overall relative performance index for each district to become as high as possible. To apply the Data envelopment analysis methodology and determine the weight, the raw values are normalized in the interval between 0 and 1 (the indicators with higher values represent the better performance of a given country and vice versa).

The basic Data envelopment analysis model assumed that sub-indexes and final CI (composite index) for each district $j(\mathrm{j}=0,1, \ldots, \mathrm{m})$ are calculated as the weighted sum of $\mathrm{n}$ indicators where the weights are endogenously determined to maximize the value of the composite index for each district (Zhou et al. 2006, Zhou et al. 2007, Cherchye et al 2007). Optimal weights should be determined by solving the next linear programming problem:

$$
C I_{j}=\max \sum_{i=0}^{n} y_{i j} w_{i j}
$$

where

$$
\sum_{i=0}^{n} y_{i j} w_{i k} \leq 1
$$

and

$$
w_{i j} \geq 0
$$

for any $\mathrm{i}=0,1, \ldots, \mathrm{n}$, any $\mathrm{j}=0,1, \ldots, \mathrm{m}$, and any $\mathrm{k}=0,1, \ldots, \mathrm{m}$.

After the calculation of weights for each sub-index using the classical "Benefit of the Doubt" approach, the DEA Cross-Efficiency model is used to rank the countries (Doyle and Green 1994).

\subsection{Composite index at the district level}

Having in mind that tourism is such complex economic activity with a vast number of factors that affecting it, Data envelopment analysis methodology is used to find the best set of certain factors (indicators) that makes appropriate business conditions for tourism development. For each sub-index which later is involved in composite index calculation, a certain number of indicators are introduced (Table 1). 
ToSEE - Tourism in Southern and Eastern Europe, Vol. 6, pp. 491-502, 2021.

Đ. Mitrović, E. Manić, S. Ivanović: BUSINESS CONDITIONS REGIONAL ANALYSIS WITH A ...

Table 1: Statistical indicators forming the composite index and sub-indexes

\begin{tabular}{|c|c|c|}
\hline Main index & Sub-index & Indicator used \\
\hline \multirow{4}{*}{$\begin{array}{l}\text { Composite } \\
\text { Index }\end{array}$} & $\begin{array}{l}\text { Tourism development index } \\
\text { (TDI) }\end{array}$ & $\begin{array}{l}\text { Foreign tourists' overnights (\%) } \\
\text { Tourism sector GVA }(\%)\end{array}$ \\
\hline & $\begin{array}{l}\text { Local Infrastructure Index } \\
\text { (LII) }\end{array}$ & $\begin{array}{l}\text { Length of roads with modern carriageway }(\%) \\
\text { Water connection rate }(\%) \\
\text { Sewerage connection rate }(\%)\end{array}$ \\
\hline & $\begin{array}{l}\text { Demographic Potential Index } \\
\text { (DPI) }\end{array}$ & $\begin{array}{l}\text { Ageing rate } \\
\text { The employment rate }(\%) \\
\text { Education }\end{array}$ \\
\hline & $\begin{array}{l}\text { Economic Development } \\
\text { Index (EDI) }\end{array}$ & $\begin{array}{l}\text { Average net salary (RSD) } \\
\text { GVA per capita (RSD) } \\
\text { Investment in fixed assets (RSD) }\end{array}$ \\
\hline
\end{tabular}

Source: Authors.

The normalized values for the 11 indicators are calculated for 25 counties in Serbia: Belgrade, West Bačka, South Banat, South Bačka, North Banat, North Bačka, Middle Banat, Srem, Zlatibor, Kolubara, Mačva, Moravički, Pomoravski, Rasina, Raška, Šumadija, Bor, Braničevo, Zaječar, Jablanica, Niš, Pirot, Podunavski, Pčinja, Toplica. The raw data for the analysis were taken from the Statistical Office of the Republic of Serbia indicators database (SORS 2020; 2021).

While researching this topic, certain constraints appeared considering the data availability: there are only a few tourism indicators that are officially monitored at the district and municipality level (Tourist arrivals and overnights, Service sector GVA within which is tourism and hospitality industry are include). Having no data on tourist consumption or tourism incomes at these levels results in a certain deficiency of the Tourism development index (TDI).

The resulting values of composite index and sub-indexes range between zero (the worst possible performance) and 1 (the best possible performance - benchmark) (Table 2).

Table 2: The composite index and sub-indexes - calculated values

\begin{tabular}{lccccc}
\hline \multirow{2}{*}{ District } & \multicolumn{4}{c}{ Sub-indexes } & Composite \\
\cline { 2 - 6 } & $\begin{array}{c}\text { Tourism } \\
\text { Development }\end{array}$ & $\begin{array}{c}\text { Local } \\
\text { Infrastructure }\end{array}$ & $\begin{array}{c}\text { Demographic } \\
\text { Potential }\end{array}$ & $\begin{array}{c}\text { Economic } \\
\text { Development }\end{array}$ & \begin{tabular}{c} 
Index \\
\hline Belgrade
\end{tabular} \\
West Backa & 0.000 & 0.984 & 0.940 & 0.633 & 0.889 \\
South Banat & 0.421 & 0.816 & 0.464 & 0.198 & 0.481 \\
South Backa & 0.779 & 0.863 & 0.734 & 0.578 & 0.649 \\
North Banat & 0.408 & 0.928 & 0.983 & 0.648 & 0.835 \\
North Backa & 0.572 & 0.822 & 0.547 & 0.298 & 0.519 \\
Middle Banat & 0.418 & 0.694 & 0.702 & 0.356 & 0.581 \\
Srem & 0.715 & 0.814 & 0.640 & 0.368 & 0.560 \\
Zlatibor & 0.516 & 0.791 & 0.640 & 0.306 & 0.619 \\
Kolubara & 0.475 & 0.588 & 0.561 & 0.197 & 0.516 \\
\hline
\end{tabular}


ToSEE - Tourism in Southern and Eastern Europe, Vol. 6, pp. 491-502, 2021.

Đ. Mitrović, E. Manić, S. Ivanović: BUSINESS CONDITIONS REGIONAL ANALYSIS WITH A ...

Table 2 (continued)

\begin{tabular}{lccccc}
\hline \multirow{2}{*}{ District } & \multicolumn{2}{c}{ Sub-indexes } & Composite \\
\cline { 2 - 5 } & $\begin{array}{c}\text { Tourism } \\
\text { Development }\end{array}$ & $\begin{array}{c}\text { Local } \\
\text { Infrastructure }\end{array}$ & $\begin{array}{c}\text { Demographic } \\
\text { Potential }\end{array}$ & $\begin{array}{c}\text { Economic } \\
\text { Development }\end{array}$ & $\begin{array}{c}\text { Index } \\
\text { Macva }\end{array}$ \\
Moravicki & 0.649 & 0.483 & 0.570 & 0.149 & 0.463 \\
Pomoravski & 0.829 & 0.670 & 0.575 & 0.222 & 0.574 \\
Rasina & 0.637 & 0.490 & 0.368 & 0.101 & 0.399 \\
Raska & 0.520 & 0.585 & 0.434 & 0.109 & 0.412 \\
Sumadija & 0.832 & 0.608 & 0.803 & 0.081 & 0.581 \\
Bor & 0.608 & 0.780 & 0.621 & 0.352 & 0.591 \\
Branicevo & 0.038 & 0.475 & 0.305 & 0.602 & 0.355 \\
Zajecar & 0.256 & 0.458 & 0.345 & 0.404 & 0.366 \\
Jablanica & 0.350 & 0.722 & 0.063 & 0.147 & 0.321 \\
Nis & 0.436 & 0.489 & 0.535 & 0.007 & 0.367 \\
Pirot & 0.734 & 0.041 & 0.676 & 0.281 & 0.433 \\
Podunavski & 0.226 & 0.516 & 0.303 & 0.361 & 0.351 \\
Pcinja & 0.800 & 0.647 & 0.551 & 0.371 & 0.592 \\
Toplica & 0.424 & 0.786 & 0.792 & 0.084 & 0.522 \\
\hline
\end{tabular}

Source: Author's calculations

\section{DISCUSSION THE RESULTS}

The proposed Composite index is used to point the differences in regional business conditions which could be further influenced by government policies to tackle the specificities and needs of each separate region during the tourism development. The calculated values of the composite index showed that north parts of Serbia have the best business conditions for tourism development, considering the different factors (total composite index and sub-indexes). As expected, the Belgrade region is placed at the top of the Composite index list with a Composite index of 0.889 (Map 1). In the case of Belgrade, all the sub-indexes show very high performances (this is the capital city region with the highest economic performance, highest in-migration rate within the country, and the region with the most developed local infrastructure). All this correspondence with the fact that Belgrade is the top number one destination in Serbia which comprises half of the foreign tourist arrivals in Serbia (Map 2).

Considering the rest of the country, the results of business conditions for tourism development are mostly expected, having in mind the economic development of certain regions and districts. So, Vojvodina region, being at the second place in the country in terms of development, has several districts which show very high potentials considering tourism development. These are Juznobacki district with Novi Sad as a center, and Juznobanatski and Sremski districts (Map 1). Novi Sad (Juznobacki district) has very high performance in all sub-indexes (Table 2). After Belgrade, Novi Sad with Juznobacki district is the second most visited city in Serbia (event tourism, European Capital of Culture in 2021, and National park Fruska gora nearby). 
ToSEE - Tourism in Southern and Eastern Europe, Vol. 6, pp. 491-502, 2021.

Đ. Mitrović, E. Manić, S. Ivanović: BUSINESS CONDITIONS REGIONAL ANALYSIS WITH A ...

On the other side, Sremski district in Vojvodina shows also good business conditions for tourism development with strong intention for developing this sector (the fixed capital investments per person and especially investments in the service sector are among the highest in the country which influences directly the GVA in the service sector and high values in tourism, Table 2). This district encompasses national park Fruska gora and directly leans on Juznobacki district (strong influence of the Novi Sad).

However, Southbanat district is at the third place considering business conditions for tourism development with a relatively low Tourism development index, but quite high performance in Local infrastructure index and Demographic potential index (it is noticeable that in all these districts in Vojvodina, and Belgrade region too, the high education share in the total population is the highest in the country). At the first glance, it seems illogical that these Vojvodina's districts, Sremski and Juynobanatski, are placed very high in the Composite index but have not so big tourism flows (Map 2). This is even more obvious with the only district from Central Serbia that belongs to the top five districts according to the business potentials for tourism - Podunavski district (Danube river right bank, some $100 \mathrm{~km}$ from Belgrade).

The next fifth places according to the Composite indexes encompass several districts in Central Serbia (Sumadija district, Raska district, and Moravicki district) and again one district from Vojvodina region (North Backa district with Palic Lake and city of Subotica). These districts in Central Serbia have a relatively solid value of Tourism development sub-index, while a relatively low value of Economic performance indicator: Sumadija district is in a slightly better position than others because it encompasses the automotive industry cluster within the city of Kragujevac.

\section{Map 1: Composite index on district level in Serbia}

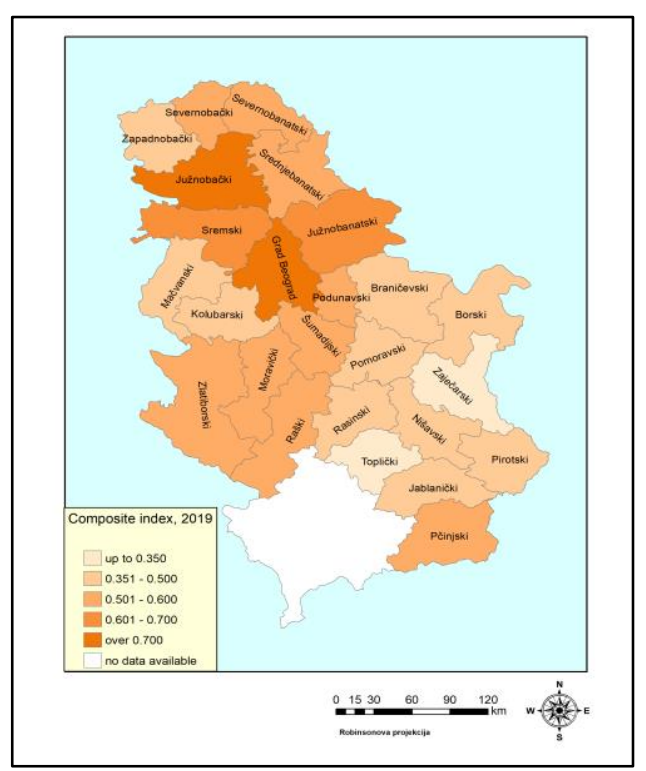

Source: Authors' calculations. 
ToSEE - Tourism in Southern and Eastern Europe, Vol. 6, pp. 491-502, 2021.

Đ. Mitrović, E. Manić, S. Ivanović: BUSINESS CONDITIONS REGIONAL ANALYSIS WITH A ...

When this ranking in Composite index is compared to the number of tourist arrivals, it is clear that tourism business conditions potentials sometimes do not correspond with tourism flow in these districts (the highest numbers of tourist arrivals have Raska district with Kopaonik mountain and Zlatibor district, and these districts show relatively low tourism business conditions potentials). The explanation lies in the fact that district level in Serbia comprises several municipalities of which may be only one has a significant number of tourist arrivals (e.g., Raska district comprises several municipalities out of which only one has high tourist figures which encompass the most of Kopaonik mountain, while the others have exceptionally low tourist performances - at average, the whole Raska district has a much lower number of tourists, Map 2).

Map 2: Total tourism arrivals in Serbia by districts, 2019

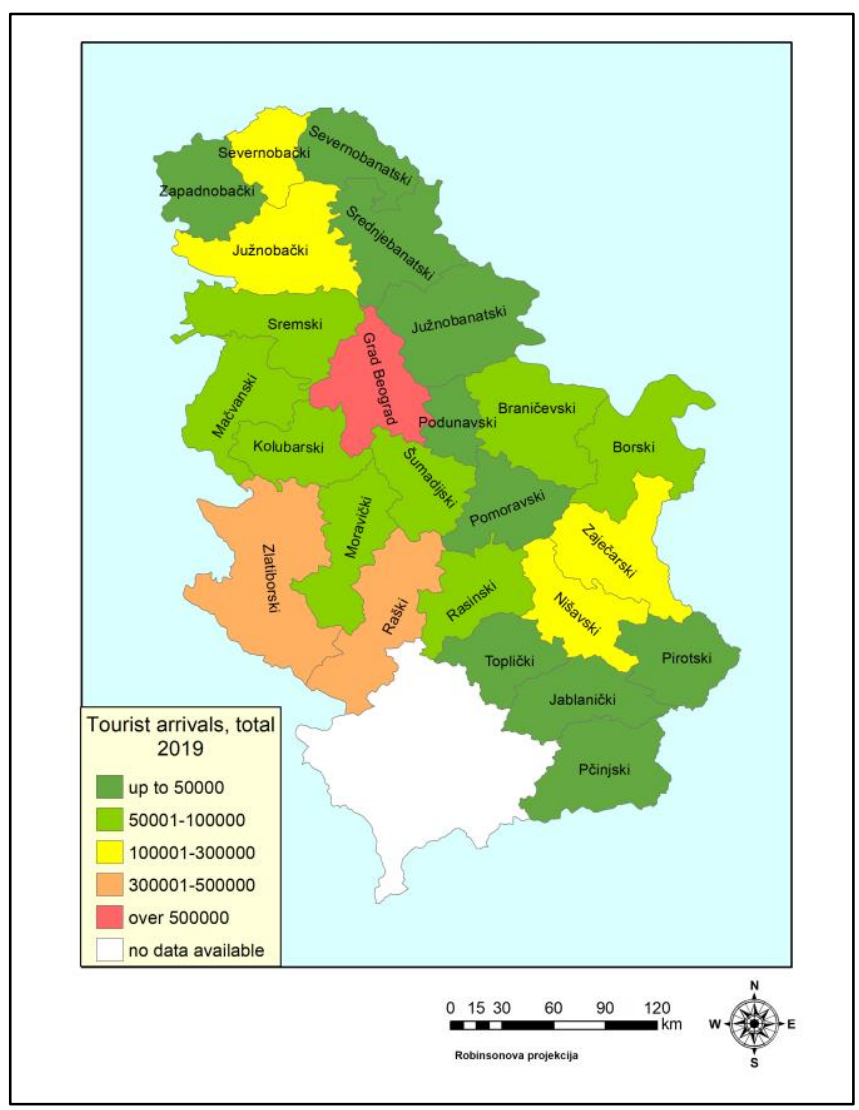

Source: Authors' calculations.

When analyzing the business conditions for tourism development within the whole district, different elements are taken into consideration within every municipality. This way municipalities within certain districts with low economic development or local infrastructure development (low values of Local infrastructure or Economic development sub-indexes) pull down the performance of the whole district. This could 
ToSEE - Tourism in Southern and Eastern Europe, Vol. 6, pp. 491-502, 2021.

Đ. Mitrović, E. Manić, S. Ivanović: BUSINESS CONDITIONS REGIONAL ANALYSIS WITH A ...

be one of the reasons why Zlatibor district in Central Serbia (with Zlatibor mountain which is one of the most developed tourism destinations - almost 400,000 tourism arrivals per year) has a relatively low value of Composite index comparing to the first five districts in the country. Both districts, Raska and Zlatibor, have low values of the Economic development sub-index. Raska has the lowest level of fixed capital investment as well as the average net salary in the country. Although Zlatibor has a little bit higher average net salary and investment rate than Raska, it still lags the top five districts regarding Composite index values in Serbia.

The lowest place in the Composite index ranking in Serbia takes districts in the east and south parts of the country. Some of these districts such as Pcinja district in the very south of the country have relatively good rank comparing to, for example, Zlatibor district. It is illogical at the first glance, knowing that there is no established tourist destination within Pcinja district. But again, potentials for future development in tourism lies in the complexity of the tourism factors interdependence: high values of demographic potentials in Pcinja district (Development potential index has high value thanks to the high birth rate which is above the national average, but also relatively high education share in the total population older than 15 years old) as well as high values in local infrastructure development (at the national average considering local water and sewage infrastructure). If we look at the future, the economic development of the area is very important, but tourism depends very much on other elements such as human resources, local specificities, local infrastructure, etc.

\section{CONCLUSION}

Data envelopment analysis is a known methodology in regional development analysis, but it hasn't been so much used in business conditions regional analysis before. Having different indicators which shaped business climate within one region, we tried by using Data envelopment analysis to analyze the entrepreneurship possibilities with a spatial reference to the tourism development. This is an important contribution in the context of local economic and social development especially within poorly developed regions in Serbia.

The calculated values of the composite index indicate the areas that economic and other policy creators should pay attention to. Tourism is just one of the sectors that give a contribute to the economic development of the country and affects its global competitiveness. The analysis presented in this paper pointed to the fact that if economic policymakers want tourism to achieve a stronger multiplier effect on all sectors of the economy, it is necessary to simultaneously support and improve not only economic but also demographic, social, and environmental factors at the district level. The example of the Zlatibor district in Serbia just shows the necessity of a different approach to the development of tourism in one country. As it was shown, Zlatibor district as a whole has a relatively low business condition for tourism development although there is one of the most visited destinations within this district. Unfortunately, the tourism development of one municipality within a district area does not mean the development of the others. And the calculated sub-indexes and the composite development index for Zlatibor district have shown that. This study reviled the mechanism of mutual factors interactions when 
ToSEE - Tourism in Southern and Eastern Europe, Vol. 6, pp. 491-502, 2021.

Đ. Mitrović, E. Manić, S. Ivanović: BUSINESS CONDITIONS REGIONAL ANALYSIS WITH A ...

the tourism sector is in question and show the direction towards which the national level of tourism development should go. It is necessary to reconsider the management destination model in Serbia. It is necessary to establish the regional level of tourism management within which the national tourism strategy will be conducted but taking into consideration the regional and local specificities. And these specificities are shaped by different factors (social, demographic, environmental, economic). More than ever before it is necessary to incorporate sustainable development principles into tourism but also overall economic development at the regional and local level. This means that certain regional destination management organizations which should plan and manage the tourism development at the district or even broader level must be introduced. In this way, the relevant instruments will be developed to improve the overall business condition at the regional level and at the same time to start diminishing existing regional disparities. This would be also the way to diminish the regional differences in tourism development as well.

\section{REFERENCES}

Adobayo, K.A. and Iweka, C.O.A. (2014), “Optimizing the Sustainability of Tourism Infrastructure in Nigeria through Design for Deconstruction Framework", American Journal of Tourism Management, Vol. 3, 1A, pp. 13-19. doi: 10.5923/s.tourism.201401.03

Adrian, S.C. (2017), "The Impact of Tourism on the Global Economic System", Ovidius University Annals, Economic Sciences Series, Vol. 27, No. 1, http://stec.univovidius. ro/html/anale/ENG/2017/SectionIV/22.pdf

Blackman, A., Foster, F., Hyvonen, T., Jewell, B., Kuilboer, A. and Moscardo G. (2004), "Factors Contributing to Successful Tourism Development in Peripheral Regions", The Journal of Tourism Studies, Vol. 15, No. 1, pp. 59-70

Blomgren, K.B. and Sorenson, A. (1998), "Peripherality - factor or feature? Reflections on peripherality in tourism research", Progress in Tourism and Hospitality Research, Vol. 4, pp. 319-336

Buhalis, D. (1999), "Limits of tourism development in peripheral destinations: Problems and challenges", Tourism Management, Vol. 20, pp. 183-185.

Calero, C. and Turner, L.W. (2020), "Regional economic development and tourism: A literature review to highlight future directions for regional tourism research", Tourism Economics, Vol. 26, No. 1, pp. 3-26. doi:10.1177/1354816619881244

Charnes, A., Cooper, W. and Rhodes, W. (1978), "Measuring the efficiency of decision making units", European Journal of Operational Research, Vol. 2, No. 4, pp. 429-444.

Che Chou, M. (2013), "Does tourism development promote economic growth in transition countries? A pane data analysis", Economic Modelling, Vol. 33, pp. 226-232. doi: 10.1016/j.econmod.2013.04.024

Cherchye, L., Moesen W., Rogge, N. and Puyenbroeck, T.V. (2007), "An introduction to 'benefit of the doubt' composite indicators", Social Indicators Research, Vol. 82, No. 1, pp. 111-145. doi:10.1007/s11205-006-9029-7

Doyle, J. and Green, R. (1994), "Efficiency and cross-efficiency in DEA: Derivations, meanings and uses", The Journal of the Operational Research Society, Vol. 45, No. 5, pp. 567-578.

Dwayer, L., Forsyth, P. and Spurr, R. (2004), "Evaluating tourism's economic effects: new and old approaches", Tourism Management, Vol. 25, pp. 307-317. doi:10.1016/S0261-5177(03)00131-6

Holzner, M. (2011), "Tourism and economic development: the beach disease?", Tourism Management, Vol. 32, pp. 923-933.

Jackson, J. and Murphy, P. (2002), "Tourism Destinations as Clusters: Analytical Experiences from the New World", Tourism and Hospitality Research, Vol. 4, No. 1, pp. 36-52.

Jackson, J., Houghton, M., Russell, R. and Triandos, P. (2005), "Innovations in Measuring Economic Impacts of Regional Festivals: A Do It-Yourself-Kit”, Journal of Travel Research, Vol. 43, pp. 360-367. doi:10.1177/0047287505274649

Jovanovic, S. and Ilic, I. (2016), "Infrastructure as important determinant of tourism development in the countries of Southeast Europe", Ecoforum Journal, Vol. 5, No. 1, pp. 288-294. 
ToSEE - Tourism in Southern and Eastern Europe, Vol. 6, pp. 491-502, 2021.

Đ. Mitrović, E. Manić, S. Ivanović: BUSINESS CONDITIONS REGIONAL ANALYSIS WITH A ...

Khanh Tuan, V. and Rajagopal, P. (2019), “Analyzing factors affecting tourism sustainable Development towards Vietnam in the new era", European Journal of Business and Innovation Research, Vol. 7, No.1, pp. 30-42.

Mayer, M. and Vogt, L. (2016), "Economic effects of tourism and its influencing factors: An overview focusing on the spending determinants of visitors", Zeitschrift für Tourismuswissenschaft, Vol. 8, No. 2, pp. 169-198. doi:10.1515/tw-2016-0017

Mitrović, Đ. (2015), "Broadband Adoption, Digital Divide, and the Global Economic Competitiveness of Western Balkan Countries", Economic Annals, Vol. 60, No. 207, pp. 95-116. doi.org:10.2298/EKA1507095M

Mitrović, Đ. (2020), "Measuring the efficiency of digital convergence”, Economics Letters, Vol. 188, 108982, doi.org:10.1016/j.econlet.2020.108982.

Nardo, M., Saisana, M., Saltelli, A., Tarantola, S., Homan, A. and Giovannini, E. (2005), "Handbook on constructing composite indicators: Methodology and user guide", OECD statistics working papers 2005/3, OECD, statistics directorate, pp. 12-14.

Vidoli, F., Fusco, E. and Mazziotta, C. (2015), „Non-compensability in composite indicators: a robust directional frontier method“, Social indicators research, Vol. 122, No. 3, pp. 635-652. doi:10.1007/s11205-014-0710-y

Nicula, V., Spânu, S., Neagu, R.E. (2013), "Regional Tourism Development in Romania - Consistency with Policies and Strategies Developed at EU Level", Procedia Economic and Finance, Vol. 6, pp. 530541. doi:10.1016/S2212-5671(13)00171-8

OECD (2008), Handbook on Constructing Composite Indicators: Methodology and User Guide. Paris: OECD Publishing.

Opperman, M. (1993), “Tourism Space in Developing Countries”, Annals of Tourism Research, Vol. 20, No. 4, pp. 535-556.

Petrova, M., Dekhtyar, N., Klok, O. and Loseva, O. (2018), "Regional tourism infrastructure development in the state strategies", Problems and Perspectives in Management, Vol. 16, No. 4, pp. 259-274. doi:10.21511/ppm.16(4).2018.22

SORS (2020), Municipalities and regions of the Republic of Serbia, Belgrade.

SORS (2021), Regional gross domestic product - Regions and areas of the Republic of Serbia, 2019, LVII, No. 115, Belgrade.

Ryan, T. (2009), The development of tourism areas: a comparative case study of the factors underpinning tourism development in Killarney and Clifden in Ireland, Doctoral thesis, Technological University Dublin, Dublin. doi:10.21427/D75S46

Santos Estêvão, C.M., Ferreira J.J. (2009), "The tourism clusters role in regional development: presenting a competitiveness conceptual model”, Tourism Destination Development and Branding Eilat 2009 Conference Proceedings, http://repositorio.ipcb.pt/bitstream/10400.11/1479/1/tourism.pdf

Sharpley, R. (2002), "The Challenges of Economic Diversification Through Tourism: The Case of Abu Dhabi", International Journal Tourism Research, Vol. 4, pp. 221-235. doi:10.1002/jtr.378

Swyngedouw, E. (2000), "Elite power, global forces, and the political economy of "global" development", in Clark, G.L., Feldman, M.P. and Gertler, M.S. (Eds.), The Oxford Handbook of Economic Geography, Oxford University Press, Oxford, pp. 541-580.

Wanhill, S. (1997), "Peripheral area tourism: A European perspective", Progress in Tourism and Hospitality Research, Vol. 3, pp. 47-70.

McIntosh R, Goeldner C. and Ritchie J. (2009), Tourism: Principles, Practices, Philosophies, Hoboken.

WTTC (2021), Economic Impact Reports 2020, The World Travel and Tourism Council.

Zhou, P., Ang B.W. and Poh, K.L. (2006), "Comparing aggregating methods for constructing the composite environmental index: An objective measure", Ecological Economics, Vol. 59, No. 3, pp. 305-311. doi: 10.1016/j.ecolecon.2005.10.018

Zhou, P., Ang B. W., and Poh, K.L. (2007). "A mathematical programming approach to constructing composite indicators”, Ecological Economics, Vol. 62, No. 2, pp. 291-297. doi: 10.1016/j.ecolecon.2006.12.020 
ToSEE - Tourism in Southern and Eastern Europe, Vol. 6, pp. 491-502, 2021.

Đ. Mitrović, E. Manić, S. Ivanović: BUSINESS CONDITIONS REGIONAL ANALYSIS WITH A ...

Đorđe Mitrović, $\mathrm{PhD}$, Associate Professor

University of Belgrade, Faculty of Economics and Business

Economic Theory and Analysis

Kamenička 6, Belgrade, Serbia

+38163217348

dorde.mitrovic@ekof.bg.ac.rs

Emilija Manić, $\mathrm{PhD}$, Professor

University of Belgrade, Faculty of Economics and Business,

Department of Economic Politics and Development

Kamenicka 6, 11000 Belgrade, Serbia

+381601989815

emilija.manic@ekof.bg.ac.rs

Slobodan Ivanović, $\mathrm{PhD}$, Full Professor

University of Rijeka, Faculty of Tourism and Hospitality Management

Primorska 46, p.p. 97, 51410 Opatija, Croatia

+385 $51294-752$

sivanov@fthm.hr 